\title{
Language Planning and Monolingual Dictionaries: With Special Reference to Ndebele*
}

\author{
Samukele Hadebe, Department of African Languages and Literature, \\ University of Zimbabwe, Harare, Zimbabwe (shadebe@arts.uz.ac.zw)
}

\begin{abstract}
The first monolingual Ndebele dictionary, Isichazamazwi SesiNdebele, had a number of effects on Ndebele, some of which with implications for language planning. One such language planning activity was the standardization of Ndebele. The article focuses on the standardization of vocabulary and spelling. Lexicographers and most of those interested in lexicographic issues are familiar with the challenges posed by what constitutes the standard vocabulary or the standard meaning of words. These questions were crucial for a general monolingual dictionary like Isichazamazwi SesiNdebele. General dictionaries are the standard dictionaries for particular languages, assumed to be reflective of the 'standard usage' of that given language in terms not only of spelling but also of meaning.

The Ndebele dictionary is based on a corpus which means that words perceived by some as foreign or as 'bad' language are considered for lemmatization. Problems were also encountered with the spelling of these loanwords. By making decisions on which words to lemmatize and how to spell loanwords, lexicographers become involved in language planning matters. The article draws from the Ndebele dictionary-making experience to discuss the role of monolingual African language dictionaries in language planning in general.
\end{abstract}

Keywords: STANDARDIZATION, GENERAL MONOLINGUAL DICTIONARY, NDEBELE, LOANWORDS, LANGUAGE PLANNING, SPELLING, STANDARD, VOCABULARY, STATUS PLANNING, CORPUS PLANNING

Opsomming: Taalbeplanning en eentalige woordeboeke: Met spesiale verwysing na Ndebele. Die eerste eentalige Ndebelewoordeboek, Isichazamazwi SesiNdebele, het 'n aantal gevolge vir Ndebele gehad, sommige waarvan met implikasies vir taalbeplanning. Een so 'n taalbeplanningsaktiwiteit was die standaardisering van Ndebele. Die artikel fokus op die standaardisering van woordeskat en spelling. Leksikograwe en meeste van diegene wat hulle in leksikografiese kwessies interesseer, is bekend met die uitdagings gestel deur wat die standaardwoordeskat of die standaardbetekenis van woorde behels. Hierdie vrae is beslissend vir ' $n$ algemene eentalige woordeboek soos Isichazamazwi SesiNdebele. Algemene woordeboeke is standaardwoordeboeke vir bepaalde tale, wat aanvaar word om die "standaardgebruik" van daardie taal te weerspieël, nie net wat die spelling nie, maar ook wat die betekenis betref.

* This article is based on a paper presented at the Tenth International Conference of the African Association for Lexicography, organized by the Sesiu sa Sesotho National Lexicography Unit, University of the Free State, Bloemfontein, Republic of South Africa, 13-15 July 2005. 
Die Ndebelewoordeboek is op 'n korpus gebaseer, wat beteken dat woorde wat deur sommige as vreemde of as "swak" taal beskou word vir lemmatisering oorweeg word. Probleme met die spelling van hierdie leenwoorde is ook teëgekom. Deur besluite te neem oor watter woorde om te lemmatiseer en hoe om leenwoorde te spel, raak leksikograwe betrokke by taalbeplanningsaangeleenthede. Die artikel steun op ervaring verkry uit die maak van 'n Ndebelewoordeboek om die rol van eentalige Afrikataalwoordeboeke in taalbeplanning in die algemeen te bespreek.

Sleutelwoorde: STANDAARDISERING, ALGEMENE EENTALIGE WOORDEBOEK, NDEBELE, LEENWOORDE, TAALBEPLANNING, SPELLING, STANDAARD, WOORDESKAT, STATUSBEPLANNING, KORPUSBEPLANNING

\section{Introduction}

The compilation of the first monolingual Ndebele dictionary, Isichazamazwi SesiNdebele, henceforth ISN, resulted in a number of language planning activities. ${ }^{1}$ The role of dictionaries in standardizing language has often been established (Chimhundu 1997, Drame 2001, Hadebe 2006, Wolff 2000). Standardization, an essential feature of language planning in general, is probably the most significant corpus planning activity carried out on Ndebele for dictionary compilation purposes. Lexicographers and most of those interested in dictionary issues are familiar with challenges posed by what constitute the standard vocabulary or the standard meaning of words. Monolingual general-purpose dictionaries like the ISN are the standard dictionaries for their respective languages and are assumed to reflect the 'standard usage' of that language in terms not only of spelling but also of meaning. Writing on the relationship of dictionaries to standard language, Alberts (2005: xiv) says: "Lexicographers compile dictionaries by (usually) documenting words in the vocabulary of a standard language. Should they compile a dictionary that does not concern the standard variety of a language it is usually called a dialectal dictionary." This observation is of significance for languages like Ndebele that could hardly be said to have had a standard prior to the production of the first monolingual dictionary and a grammar book.

In this article, it is shown how the ISN has an impact on language planning by presenting an overview of the notion of language planning, discussing the significance of monolingual dictionaries, outlining the sociolinguistic situation of Ndebele and sketching the language planning activities resulting from the production of the ISN.

\section{What is Language Planning?}

Language planning as a concept is problematic not only because of the different meanings attached to it but also because the possibility of planning a language is questionable. Partly for this reason, there has so far been no consensus among scholars on a definition of language planning. This is reflected in the 
great variety of terms that exist to describe language planning. These include the terms linguistic reform, language reform, deliberate language change, planned language change and language treatment as well as terms such as language engineering (Pauwels 1998: 2) and lately language management (Ntshangase 1997: 17).

Language planning has been defined as "an explicit choice among (linguistic) alternatives" (Fasold 1984: 246), or as "a deliberate language change ... characterized by the formulation and evaluation of alternatives for solving language problems to find the best (or optimal, most efficient) decision" (Rubin and Jernudd 1971: xvi). Jernudd and Das Gupta (1971: 211) define it as "an orderly decision-making about language on a national level". Mkanganwi (1992: 6) sees it as "the conscious, predictive approach to language and language use". From these views on language planning, some of the key concerns of language planning may be drawn. Firstly, the issue of language diversity and hence the choice among many alternatives may be noted. Secondly, language planning is not accidental but intentional, hence the terms 'conscious', 'orderly decisionmaking' and 'deliberate'. It then introduces the question of who does language planning and why. Language planning is always directed towards a certain goal in order to solve perceived language problems. Language planners are "the wielders of political-economic power in a state, nation, or nationalising entity" (Eastman 1992: 96). Jernudd and Das Gupta (1971: 196) say: "The broadest authorization for planning is obtained from the politicians. A body of experts is then specifically delegated the task of preparing a plan."

The view that language authorization comes from a central authority has been challenged by some scholars like Bamgbose (1991) and Alexander (1992) as there are numerous players in language planning. Some of these are nongovernmental, such as publishers, the media, churches and individuals. It should also be noted that language planning is a very broad activity involving both political and linguistic decisions. The more political aspects seem to be those relating to status planning while the linguistic aspects involve corpus planning activities. For this reason, it can be said that language planning includes all the activities ranging from selection and delegation of functions to each variety to codification, fixing grammar and pronunciation rules as well as elaborating the various features of the language and the implementation of these plans (Hadebe 2006). Unlike status planning, corpus planning is usually an on-going process, which can be carried out in anticipation of the possible functions the language might have in future or may be performed in order for the language to cope with functions it is already serving. The production of the ISN had a more significant impact on corpus planning than on status planning as will be shown in this article. To be more specific, the dictionary had a standardizing influence on Ndebele.

\section{Monolingual Dictionaries in Society}

Monolingual general-purpose dictionaries are mostly assumed to represent 
and reflect the lexicon of the language in question and hence the richness of its culture. Therefore, these dictionaries are seen not only as linguistic tools but also as repositories of a particular people's culture. Béjoint (2000: 137-138) writes:

General-purpose dictionaries occupy a very special position in all the societies that produce them ... The emblematic power of the general-purpose dictionary is so strong, so real in a way, that the dictionary is felt to be necessary to any nation that wants to be recognized as an independent entity. It is one of the rare objects that can materialize the existence of a language, and hence of a nation, acting as a symbol of the unification of a community.

This cannot be nearer the truth regarding the impact of the ISN on the Ndebele. Being the first monolingual dictionary and being the first research work of its kind, the ISN received nation-wide publicity and caused public excitement after its appearance. It can safely be claimed that the dictionary will be the standard reference work for the Ndebele language for quite some time (Hadebe 2006: 29). The Ministry of Education and Culture actually prescribed the ISN as a reference book in schools. In the prestigious National Arts Merits Awards (NAMA) of 2002, it won a first prize in the non-fiction literary award category while its editor-in-chief jointly won the first prize. All these factors added national prestige to the status of the dictionary.

While the editors of the ISN may claim that their dictionary is descriptive, in reality there is no dictionary that can be entirely descriptive. "Dictionaries not only describe a language. Many modern dictionaries are prescriptive works" (Drame 2001: 232). Editors choose which words to define; they also choose how to define and spell them. Even if editors include various pronunciations and spellings for each entry, they still give guidance on which usage is preferable, thus being prescriptive (Hadebe 2006: 29). On the other hand, dictionary users usually assume and expect the dictionary to give them the 'correct' spelling, pronunciation and usage. They furthermore expect the generalpurpose dictionary to give them the 'standard' language. Fasold (1984: 247) accentuates this: "Whenever you look up a word in a dictionary to find a correct spelling, you are referring to an authority's language-development decision." What should be noted in this statement is the normative function of dictionaries (Svensén 1993: 45). Chimhundu (1997: 140) says: "A standard dictionary has an important normative influence, as the users accept and apply the lexicographer's descriptions of word-forms and his statements about their meanings. The dictionary is also the chief instrument in interpreting rules about spelling and pronunciation." For a language with little documentation like Ndebele, the production of a monolingual general-purpose dictionary like the ISN contributed to language planning such as, for example, the standardization of spelling, word division and vocabulary. The dictionary tends to be the main reference source to verify the 'correctness' of spelling or to authenticate the usage of some words or expressions (Hadebe 2006: 29). 
The current status of the ISN as 'the dictionary' amongst the Ndebele is not peculiar but prevalent in most societies. Generally the monolingual dictionary follows the bilingual dictionary although this is not the case everywhere. For Ndebele, the ISN came after a bilingual English-Ndebele/NdebeleEnglish publication, A Practical Ndebele Dictionary compiled by Pelling. It is interesting to analyze the conditions that led to the rise of the monolingual general-purpose dictionary - often referred to as 'the dictionary'. In Europe, these dictionaries coincided with the introduction of mass education and the development of bourgeoisie nationalism. In Zimbabwe, they became popular after independence, together with nationalist literature in the African languages. The popularity, influence and resultant standardizing function of the ISN should be seen as a consequence of this nationalistic spirit that usually accompanies the emergence of monolingual dictionaries. Similarly, the concerns about language purism discussed below (see 5.1.2) should also be considered from this perspective. Heightened nationalist feelings seem to correlate with heightened language purism.

\section{Ndebele in the Zimbabwean Language Landscape}

The position of Ndebele within the Zimbabwean language landscape is a precarious one. By language landscape is meant "an accurate picture of the languages, both foreign and native, used in a given geographical area" (NdingaKoumba-Binza 2005: 133). It should be noted that Zimbabwe does not have a clear language policy (Mkanganwi 1992, Chimhundu 1997). However, English, Ndebele and Shona are recognized in the Constitution as the three main languages. English is the official medium of instruction in Zimbabwean schools although indigenous languages can be used at primary level. Ndebele is only taught as a subject in the two Matabeleland provinces and in some schools in the Midlands province. Shona is taught in the rest of the country.

Zimbabwe also has a number of indigenous African languages designated as 'local languages'2, some of which are Tonga, Venda, Nambya, Kalanga and Shangani. Ndebele is in a precarious position because, unlike Shona which enjoys numerical superiority and political prestige, Ndebele is strictly speaking a minority language in Zimbabwe. When compared to Shona, Tonga, Venda or Kalanga, it is a relative newcomer in the history of the country. Almost all the local languages are in Matabeleland where Ndebele is currently dominant (Hadebe 2002: 161). Therefore, a promotion of the status of local languages might be perceived, as previously it has been viewed as an attempt to undermine Ndebele (Hachipola 1998: xx).

Together with the relative advantage of being taught in schools in Matabeleland, the strength of Ndebele is that it serves as the lingua franca for the speakers of local languages (Hadebe 2006: 62). This apparent strength turns out to be a disadvantage for the Ndebele language planner, for example, in the compiling of the ISN, the editors had difficulty in deciding whether or not to 
lemmatize loanwords from these other languages. While this seemed the logical way to follow as the dictionary relied heavily on a corpus (see Hadebe 2002), in reality this was not possible. The Ndebele people in general and those of Nguni stock in particular want the Ndebele language to be kept as close as possible to Zulu.

The close links between Zulu and Ndebele seem bound to continue for some time. In any case, Zulu has been and continues to be studied as part of the Ndebele syllabi for secondary education as well as at university level (Hadebe 2006: 62). So the ISN editors had to balance between the scientific evidence provided by the corpus and the sociolinguistic factors dictated by culture, history and speakers' attitudes. The former choice meant including loanwords from local languages and others like Shona, while the latter choice meant keeping the vocabulary very close to Zulu regardless of the fact that no one speaks Zulu.

\section{The Ndebele Dictionary, Isichazamazwi SesiNdebele}

By basing the ISN on a corpus, its compilers aimed to reflect as much as possible the language used by contemporary mother-tongue speakers. In the front matter of the ISN, the editors also reiterate their claim to describing rather than prescribing the language. As already noted above, dictionaries, especially general-purpose standard ones like the ISN, cannot be entirely descriptive. Of course, it has been argued since long ago already that the lexicographer is a historian, not a critic, his duty being to record the inventory of the language without judging it in terms of good or bad (Trench 1857: 3-4). While the editors of the ISN did not necessarily judge some words as good and others as bad, choices had nonetheless to be made resulting in the exclusion of some words for a variety of reasons. According to Follett (1962: 77), "the lexicographer cannot abrogate his authority even if he wants to ... the work itself by its inclusions and exclusions is perceived as the absolute truth". The focus areas here are vocabulary and spelling although these are not the only language planning activities which resulted from the compilation of the ISN.

\subsection{Vocabulary Planning}

Vikør (1999: 1) says:

To plan the vocabulary of a language is vastly ... complicated, since it consists of a fundamentally infinite mass of units restricted by the limits of our mental capacity. Vocabulary changes and develops spontaneously, more or less, as words change meaning, gradually or more rarely abruptly, or change stylistic valor, gradually fall into disuse when they are no longer needed, or are created as neologisms ... This is a development which, one should think, is difficult enough to describe, and virtually impossible to plan or standardize. 
At face value, it would seem that Vikør implies that vocabulary cannot be planned, yet he later enumerates a number of ways of vocabulary planning, although difficult to achieve.

The compilers of the ISN did not set out to plan or standardize Ndebele vocabulary, or spelling for that matter, but language planning was the byproduct of dictionary-making. In addressing what were lexicographic problems, the compilers found themselves engaged in language planning challenges and had to make decisions that had a profound impact on the standardization of Ndebele.

Some of the aspects of language planning addressed by ISN editors discussed below are norm selection and language purism. The discussion also covers briefly how spelling problems regarding loanwords were dealt with.

\subsubsection{Norm Selection}

Norm selection is an important aspect of standardization, which involves the choice of one or more varieties to serve as standard reference for a language. For Ndebele to be reflected in the ISN, the problem of norm selection was of a double kind. On the one hand, applied the norm of the Ndebele corpus where choices among the varieties of Zulu had to be made. On the other hand, applied the norm of Zulu where a policy of close relationship to Zulu had to be followed.

Prior to the building of the Ndebele language corpus by the ALLEX Project the general view in Zimbabwe was that Ndebele had no variations. As Chimhundu (1993: 58) put it:

Unlike Shona, Ndebele has no dialects or regional varieties as such. However, there are certain forms and usages that are peculiar to people of particular areas as the result of influences of other languages spoken in those areas, notably Kalanga in Plumtree, Lilima (Tswana?) in Gwanda, Lozi in Hwange, Shangwe in Gokwe-Nkai and Shona in Gweru - Midlands.

This observation is valid only in so far as the variation in Ndebele is not the same as that of Shona and its distinct geographical dialects. In any case, no language can in all aspects be compared with another. Evidence from the Ndebele language corpus shows that there is considerable variation in Ndebele although it is not easy to delineate this variation according to geographical distribution.

As already noted, this apparent confusion can be attributed to the sociolinguistic situation in Matabeleland where Ndebele is spoken alongside other indigenous languages. It could be argued that, although variation in Ndebele is largely attributed to the influence of other indigenous languages and seen as confined to speakers of Ndebele as their second language, there is variation in Ndebele among mother-tongue speakers too. As vocabulary items can come from all these potential sources, it is now the task of the lexicographer to decide whether certain words have been accepted into the mainstream or not. 
Although few present-day Ndebele people can trace their ancestry to Zululand, nevertheless almost everyone believes that Ndebele originated from the Zulu language. Because of this, the reasoning is that Ndebele must be kept as close as possible, if not similar to Zulu. The situation is compounded by the fact that Ndebele in Zimbabwe is taught alongside Zulu from high school to university. The teaching of Ndebele, be it grammar, literature, poetry or culture, relies on Zulu books (Hadebe 2006: 136). For this reason, the vocabulary used in formal education and in books is either Zulu or akin to Zulu. Any changes that cannot be accounted for in Zulu are likely to be resisted by a large section of Ndebele speakers (Hadebe 2006: 136). The compilers of the ISN could scarcely ignore the Zulu factor and still hope to produce an acceptable Ndebele dictionary.

\subsubsection{Language Purism}

Language purism, "a prescriptive approach to language which favours native over foreign words" (Hartmann and James 1998: 113), is one other form of language planning pertaining to vocabulary. In Ndebele, it can be explained in terms of the sociolinguistic factors affecting Ndebele in relation to other languages as well as its historical ties with Zulu (see Ncube 2005: 295). Hadebe (2006: 136) explains this as follows:

As a language, Ndebele found itself surrounded by languages very different from and yet co-existing with it. That may partly explain the high degree of purism as a form of protection from the pervasive influence of the languages in the region. Where the speakers felt threatened by new words from languages in the region, they would instead adopt Zulu words rather than use words from their neighbouring languages. This purism extends even to words from English, which is perceived as superior to Ndebele.

Like all living languages, Ndebele is obviously losing this battle for purism as more and more words are introduced into the language. What is of importance here is how the editors of the ISN dealt with purism. There were two principles that guided selection of entries: first was the frequency of a word as reflected in the concordances drawn from the corpus, and second was the preference for indigenous words over loanwords. From the outset, it was clear that the second principle curtails and overrides the first principle. In practice, it is evident from the Ndebele language corpus that lemmatization was influenced more by what compilers believed were indigenous words than by what the evidence of highfrequency use from the corpus was.

The following are examples of words with a high frequency in the Ndebele corpus that were excluded from the ISN:

ubutindindi (type of mushroom)

izitatangwa (swamps)

-tshotshola (pounding maize) 
-petsha (to sieve)

-kwaya (to dig)

While these are now common words in spoken Ndebele as reflected in the corpus, they are, however, still considered unacceptable by the more conservative members of Ndebele society, the reason being that since these words derive from Kalanga or its related dialects, they should therefore not be part of Ndebele vocabulary.

There was also another guiding principle in the style manual explicitly stating that in the event of a loanword being synonymous with an indigenous word in the language, the indigenous word should carry the definition. The following are some examples:

$\begin{array}{ll}\text { indigenous word } & \text { loanword } \\ \text { ubabhemi } & \text { idonki (adapted from English) (donkey) } \\ \text { umongikazi } & \text { unesi (adapted from English) (nurse) } \\ \text { umkhongi } & \text { idombo (from Kalanga) (marriage-go-between) }\end{array}$

It may be asked: Did the editors apply the principle of higher frequency in the corpus or did they give priority to less used words merely because they sound more original to the language? The answer is clear from evidence in the ISN that the editors gave preference to what was considered a more indigenous word, even if corpus evidence showed overwhelmingly that the word was less used, as was the case with umkhongi (compared to idombo) under the examples given above. The concern for revivalism meant that words perceived to be indigenous to Ndebele had to be promoted even if that violated the rule of high frequency.

The preference for indigenous words was not pursued to the absolute exclusion of loanwords. Ndebele has borrowed extensively from English, especially words relating to modern fields ranging from agriculture, industry and commerce to sports and religion. Goods that are either factory made or imported come to the Ndebele community with English labels. Although there are attempts to coin indigenous Ndebele words, the process cannot cope with, let alone rival, the loanwords from English. The ISN lists many loanwords from English but, where there is an indigenous Ndebele word equivalent, this carries the definition.

It should be noted that there are some words in everyday spoken Ndebele that are resisted in writing because they are considered not to be Ndebele. One much debated word is the verb -kwanisa (be able). Language purists and teachers would insist that the word -enelisa (be able) should be used instead as this is considered good and appropriate language. The ISN did not lemmatise -kwanisa even though it is more common than -enelisa, for fear of it being labelled foreign or 'bad' language. There are also words with sounds that are resisted by some sections of the Ndebele-speaking community, especially the elderly. Although the affricate $/ \mathrm{dz} /$ is not original to Ndebele, a number of words with this sound currently exist. Instead of articulating the sound /dz/ some speak- 
ers replace it with $/ \mathrm{j} /$. Most words with these sounds have become variants like in the following examples:

$$
\begin{aligned}
& \text { udzidziyane - ujijiyane (blue waxbill) } \\
& \text { ubudzugwe - ubujugwe (type of mushroom) } \\
& \text {-dzimila - jimila (to be lost and have memory lapses) }
\end{aligned}
$$

These examples illustrate the problems encountered by editors in headword selection and in defining. When the ISN was published, there was much response to this vocabulary selection. A notable Ndebele writer and historian congratulated the ISN editors for including words with $\langle\mathrm{r}\rangle$ :

$$
\begin{aligned}
& \text { iringi (ring) } \\
& \text { ireshini (ration) } \\
& \text { irediyetha (radiator) }
\end{aligned}
$$

Some were of the opposite view, expressing deep concern over the inclusion of words with $\langle\mathrm{r}\rangle$ that they felt were not 'proper' Ndebele. The word they complained most about is ishamari (illicit lover), derived from the Shona shamwari (friend). From some of the responses, the conclusion can be drawn that Ndebele purism is selective and targeted against words from specific languages whose speakers are disliked or disdained for whatever reason. According to Ncube (2005: 299), "some users of ISN are comfortable to accept the /r/ sound in words such as irula (ruler) and irobhothi (robot), but are not comfortable when the same sound appears in words such as ishamari". It is an observed fact that "vocabulary selection policy inevitably reflects the interests, concerns and culture of the time" (Jackson and Amvela 2000: 163).

What all the above observations show is the overriding considerations for language planning. Since general-purpose standard dictionaries are assumed to be descriptive and not prescriptive, the ISN should then be expected to have lemmatized all high frequency words from the corpus but it did not always do so. Maybe attempts to forestall criticism and rejection from purists led editors to violate the principle of lemmatizing high frequency words from the corpus, instead promoting those words that are generally perceived to be more indigenous and 'authentic' Ndebele. The ISN, like any dictionary of its type, does not only reflect the prevailing language policy, but is itself an agent of language planning, especially with regard to vocabulary.

\section{$5.2 \quad$ Spelling}

A big challenge to the editors of the ISN was the spelling of loanwords. In cases where there could be no consensus on spelling, the editor-in-chief had to use his discretion. Loanwords firstly bring into Ndebele sounds that previously were not in the language, making it difficult to represent them in writing (Hadebe 2006: 138). Secondly, loanwords violate the sequences of phonemes acceptable to Ndebele. 
The spelling issues discussed here are in two ways important for orthography standardization. Firstly, they show the problems the editors of the ISN had to face. Secondly, whatever decision the editors made has significance for language planning. Unlike the study of vocabulary standardization which remains vague and uncertain, the standardization of spelling is more concrete and direct, thus likely to be easily noticed by language users. However, the complicating factor was that the editors of the ISN had no mandate to make spelling reforms. They did not want to have their dictionary rejected by the authorities on the grounds that it had an unacceptable spelling. It was considered easier to defend the inclusion of particular words in the dictionary against criticism than the violation of certain spelling conventions. The following were some of the problem cases:

\section{(a) The voiced alveolar trill [r]}

Originally, the Ndebele phonological system did not have the voiced alveolar trill [r] represented in the Ndebele orthography by the letter $\langle\mathrm{r}\rangle$. The $/ \mathrm{r} /$ sound which is not original to Ndebele is now part of it, at least of spoken Ndebele, due to the influence of other languages, especially English and other African languages like Sotho and Shona. Language purists among the Ndebele people are opposed to the use of $/ \mathrm{r} /$, and whenever this sound is to be used, they replace it with $/ 1 /$ written $\langle 1\rangle$.

The controversy about / $\mathrm{r} /$ did not end with arguments on the acceptability of the phoneme as part of the inventory of the Ndebele phonological system but extended to the alphabet. The use of the letter $\langle\mathrm{r}\rangle$ is still being resisted in Ndebele although it seems the $/ \mathrm{r} /$ sound is now prevalent in speech. For some reason, it has been assumed that the $/ \mathrm{r} /$ sound is a distinguishing feature of Shona while / $/$ has been seen as typically Ndebele. It would seem that this perception is mutual between Shona and Ndebele speakers. ${ }^{3}$ The response to the $\langle\mathrm{r}\rangle$ has already been mentioned above under 5.1.2, together with a discussion of examples.

\section{(b) The voiced alveolar affricate [dz]}

Another sound that is still controversial in Ndebele is the voiced alveolar affricate [dz], which is also found in other Zimbabwean languages like Shona, Venda and Kalanga. In some Ndebele words, this $\langle\mathrm{dz}\rangle$ has been substituted by $\langle j\rangle$. Why it is resisted is unknown. It would seem that the /dz/ has replaced other sounds in Ndebele, as can be seen from the following examples:

ugcigciyane (blue waxbill) 
The original name of the bird is ugcigciyane but some speakers probably had difficulties with the click sounds and substituted those with $/ \mathrm{dz} /$, saying udzidziyane. Now some speakers avoid /dz/, replacing it with $/ \mathrm{j} /$ and saying ujijiyane.

There are a number of loanwords that have /dz/ substituted by some speakers with $/ \mathrm{j} /$, as in the following examples:

$$
\begin{aligned}
& \text { ubudzugwe (type of mushroom) } \quad\langle\mathrm{dz}\rangle \\
& \text { ubujugwe }\langle\mathrm{j}\rangle \\
& \text { ukudzimila (to be confused, losing one's sense of direction) }\langle\mathrm{dz}\rangle \\
& \text { ukujimila }
\end{aligned}
$$

These words have become either synonymous or are freely variable, both spellings $\langle\mathrm{dz}\rangle$ and $\langle\mathrm{j}\rangle$ having been used in Ndebele.

While some Ndebele speakers resist the affricate /dz/ on the grounds that it is not Nguni and therefore not Ndebele, it is actually found in related Swati although in different phonological environments than in Ndebele. For example, in Swati the voiced alveolar stop /d/ would change into the affricate /dz/ when followed by the vowels /a/, /e/, or /i/.

\section{(c) The voiced postalveolar fricative [3]}

The voiced postalveolar fricative [3], orthographically represented in Ndebele by the digraph $\langle z h\rangle$, which is found in place names like eBezha, eBhazha and eZhilo in Ndebele-speaking areas, has been accepted in Ndebele. Some might argue that these names are in fact not Ndebele but come from the dialects Kalanga or Nyubi. Words spelt with 〈zh〉 like ibhizha (butter from cowpeas) have been lemmatized in the ISN without any complaints being received.

\section{(d) Unacceptable clusters}

The editors of the ISN had to deal with thousands of loanwords containing unacceptable clusters but having become part of everyday language. Because there are currently no comprehensive rules on Ndebele orthography, writers either use italics or the English spelling for these words. In the dictionary, none of these strategies were suitable; the loanwords had to be spelt one way or the other. Below are some examples:

$$
\begin{aligned}
& \text { isiliva (silver) } \\
& \text { isikweya (square) } \\
& \text {-fulasha (flash) }
\end{aligned}
$$

Now that the ISN has been endorsed officially by the Ministry of Education and Culture, which therefore means that it may be used in all schools as a reference book, the spelling and word division employed in the dictionary has become official. 


\section{Implications for Language Planning in Ndebele}

Since the spelling reforms of the 1950s, the production of the ISN was probably the most significant language planning activity in the Ndebele language. In terms of vocabulary development and spelling regulation, the ISN is as yet unparalleled. So far the ISN has undoubtedly been instrumental in the standardization of the Ndebele language, especially as far as vocabulary and spelling are concerned.

What might have given rise to the proliferation of different spellings, especially of loanwords, was the lack of an up-to-date guide to spelling and word division. This was further worsened by the lack of a comprehensive monoingual Ndebele dictionary, which could be used as a reference source for problematic spelling and word division. Although there is still no up-to-date guide to Ndebele orthography, there is a comprehensive Ndebele dictionary (Hadebe 2006: 189) which can at present be employed for reference purposes. Teachers and writers would have to rely on it for 'standard' spelling. In this way, the ISN has become the standardising instrument for Ndebele orthography.

The fact that the ISN has been based on the Ndebele language corpus had the capturing of current language usage as a result. However, the basing of the ISN on the Ndebele language corpus meant the inclusion of some words and meanings perceived by some as foreign or slang or even as 'bad' language. There were concerns about the lemmatization of some words considered not Ndebele. Loanwords, especially from English and other indigenous languages, have become part of everyday Ndebele vocabulary, the question for the lexicographer being whether to lemmatize these or not. Those words included in the dictionary have been endorsed as part of Ndebele while those excluded have been rejected. In this way, the ISN has played a crucial role in Ndebele vocabulary planning.

\section{Conclusion}

The lexicographer, especially the one compiling a monolingual African language dictionary like the ISN, should take into cognizance language planning issues. It was shown how the ISN has been instrumental in vocabulary planning and spelling standardization in Ndebele. While the compilers of the ISN did not set out to directly engage in language planning, nonetheless their lexicographic activities had significant language planning effects on Ndebele. It was also noted that language planning is goal-oriented, aiming to solve perceived language problems. Lexicographers treating African languages therefore face language planning challenges like codification, spelling reform, norm selection, elaboration and general standardization problems they have to resolve. Furthermore, the function of dictionaries as standard reference works strengthen the role of lexicographers as language planners. In this way, language planning is inevitably linked to monolingual lexicography. 


\section{Endnotes}

1. The writer as the editor-in-chief of Isichazamazwi SesiNdebele is drawing from practical experience. These issues have also been discussed in his doctoral thesis entitled The Standardisation of the Ndebele Language through Dictionary-Making.

2. In the Education Amendment Bill, 2005, the term 'minority' has been substituted by 'local' languages and these can now be used as medium of instruction for primary education.

3. For example, the monolingual Shona dictionary Duramazwi reChiShona avoided entries with /1/ but the later advanced version Duramazwi Guru reChiShona uses the /1/.

\section{References}

\section{Dictionaries}

Chimhundu, H. (Ed.). 1996. Duramazwi reChiShona. Harare: College Press.

Chimhundu, H. (Ed.). 2001. Duramazwi Guru reChiShona. Harare: College Press.

Hadebe, S. (Ed.). 2001. Isichazamazwi SesiNdebele. Harare: College Press.

Hartmann, R.K.K. and G. James. 1998. Dictionary of Lexicography. London: Routledge.

Pelling, J. 1966. A Practical Ndebele Dictionary. Harare: Longman Zimbabwe.

\section{Other Literature}

Alberts, M. 2005. A Few Words from AFRILEX. Lexikos 15: xiv-xv.

Alexander, N. 1992. South Africa: Harmonising Nguni and Sotho. Crawhall, N. (Ed.). Democratically Speaking: International Perspectives on Language Planning: 56-68. Cape Town: National Language Project.

Bamgbose, A. 1991. Language and the Nation. Edinburgh: Edinburgh University Press.

Béjoint, H. 2000. Modern Lexicography: An Introduction. Oxford: Oxford University Press.

Chimhundu, H. 1993. The Status of African Languages in Zimbabwe. Southern African Political and Economic Monthly 7(1): 57-59.

Chimhundu, H. 1997. Language Standardisation without Policy or Planning: Zimbabwe as a Case Study. Røyneland, U. (Ed.). Language Contact and Language Conflict: 129-150. Volda: Volda College.

Drame, A. 2001. Foreign Words as a Problem in Standardisation/Lexicography: English and Afrikaans Loan-words in isiXhosa. Lexikos 11: 231-241.

Eastman, C.M. 1992. Sociolinguistics in Africa: Language Planning. Herbert, R.K. (Ed.). 1992. Language and Society in Africa: The Theory and Practice of Sociolinguistics: 1-19. Johannesburg: Witwatersrand University Press.

Fasold, R. 1984. The Sociolinguistics of Society. Oxford: Blackwell.

Follett, W. 1962. Sabotage in Springfield: Webster's Third Edition. The Atlantic 209: 73-77.

Hachipola, S.J. 1998. A Survey of the Minority Languages of Zimbabwe. Harare: University of Zimbabwe Publications.

Hadebe, S. 2002. The Ndebele Language Corpus: A Review of Some Factors Influencing the Content of the Corpus. Lexikos 12: 159-170. 
Hadebe, S. 2006. The Standardisation of the Ndebele Language through Dictionary-Making. Harare/Oslo: The ALLEX Project.

Jackson, H. and E.Z. Amvela. 2000. Words, Meaning and Vocabulary. London/New York: Cassell.

Jernudd, B.H. and J. Das Gupta. 1971. Towards a Theory of Language Planning. Rubin, J. and B.H. Jernudd (Eds.). Can Language Be Planned? Sociolinguistic Theory and Practice for Developing Nations: 195-216. Honolulu: The University Press of Hawaii.

Mkanganwi, K. 1992. Language Planning in Southern Africa. Crawhall, N. (Ed.). Democratically Speaking: International Perspectives on Language Planning: 6-11. Cape Town: National Language Project.

Ncube, C. 2005. Language Development or Language Corruption? The Case of Loan-words in Isichazamazwi SesiNdebele. Lexikos 15: 294-305.

Ndinga-Koumba-Binza, H.S. 2005. Considering a Lexicographic Plan for Gabon within the Gabonese Language Landscape. Lexikos 15: 132-150.

Ntshangase, D. 1997. Society in Transition. The Feasibility of Technical Language Development in the African Languages: 17-20. Pretoria: Department of Arts, Culture, Science and Technology.

Pauwels, A. 1998. Women Changing Language. London/New York: Longman.

Rubin, J. and B.H. Jernudd. 1971. Language Planning as an Element in Modernization. Rubin, J. and B.H. Jernudd (Eds.). 1971. Can Language Be Planned? Sociolinguistic Theory and Practice for Developing Nations: xiii-xxiv. Honolulu: The University Press of Hawaii.

Svensén, B. 1993. Practical Lexicography: Principles and Methods of Dictionary-Making. Oxford: Oxford University Press.

Trench, R.C. 1857. On Some Deficiencies in Our English Dictionaries. Transactions of the Philological Society (1857): 1-60

Vikør, L.S. 1999. Vocabulary Planning - A Tricky Business. Lecture at the ALRI Launching Seminar, Harare.

Wolff, H.E. 2000. Language and Society. Heine, B. and D. Nurse (Eds.). 2000. African Languages: An Introduction: 298-347. Cambridge: Cambridge University Press. 